\title{
Violence and health in Colombia ${ }^{1}$
}

\author{
Saúl Franco Agudelo²
}

ABSTRACT In Colombia, violence seems uncontrollable. Along with massacres and group killings of astonishing cruelty, there are also kidnappings and disappearances, abuse of children and the elderly, and rape of young adolescents. Every day, without respite, Colombians are witnesses or victims of street crimes as well as racial, sexual, and socioeconomic discrimination. Unwillingly, they become agents of aggression in public transport, at home, at school, and at work.

Colombia has the highest rates of mortality from homicide in the world. Apart from the enormous institutional burden that violence imposes on the health services and forensic medicine, it now constitutes the principal public health problem in the country. To confront it, the health sector must develop policies and finance actions, develop innovative ways to train personnel, implement public education processes, and devote more effort and greater creativity to research, which up to now has provided some important, albeit insufficient, responses.

Violence, which is the substitution of force for any type of dialogue, must be considered within the context of life and health. Doing so is not an attempt to rationalize violence, much less to substitute words or reflection for action, but rather an attempt to understand it in depth in order to search for alternatives.

With that goal, this article analyzes the subject of violence in Colombia, principally from the perspective of its effect on the health of the citizens and its implications for the health sector. The author fully recognizes the subjectivity and limitations of the views he expresses herein.

Until the mid-1970s in Colombia, the term "La Violencia" (The Violence) had a precise meaning: those acts of force, many of considerable cruelty, committed within the framework of political and party interests between 1948 and 1964. An extensive bibliography-including such works as La vio-

\footnotetext{
1 This article has been published in Spanish in this journal (1997, Vol. 1, No. 2, pp. 93-103) under the title "Violencia y salud en Colombia."

2 National University of Colombia, Institute of Political Studies and International Relations, Santa Fe de Bogotá, Colombia. Mailing address: Director, Corporación Salud y Desarrollo, Apartado Aéreo 57736, Santa Fe de Bogotá, Colombia. E-mail: sfranco@gaitana.interred.net.co.
}

lencia en Colombia (1), a classic account that served to launch the study of violence in Colombia, and Once ensayos sobre La Violencia (2)-treats La Violencia as a unified thematic and chronologic phenomenon, albeit with obvious variations in focus, emphasis, and interpretation.

An increase in violence of all types at the beginning of the 1980s led to talk of a "nueva violencia" (new violence) and abandonment of the prevailing temporal connotation of the term to focus on new questions and problems. An advisory group convened by the national government to address the subject in 1987 attempted to develop a system for classifying violence and suggested structural and symptomatic alternatives. In order to avoid unnecessary fragmentation of the topic, the group opted to define violence in its report as "all those actions of individuals or groups that cause death to others or injure their physical or moral integrity. In a very general sense, violence can be seen as something that prevents realization of Human Rights, beginning with the most fundamental: the right to life" (3). In this view, violence emerges as a harmful human activity that diminishes integrity and limits rights.

The document cited constitutes a landmark in defining both the concept 
and the problem of violence in Colombia. Since its publication, violence in Colombia has begun to be recognized as a polymorphous, multicausal entity present throughout the individual and social fabric.

In a number of previous works $(4,5)$ I have described several theories about this complex problem. Briefly, violence is the imposition of force in the service of a particular interest or group of interests. It consists of acts committed asymmetrically and in a specific direction, with the consequent denial or limitation of one or more of the rights of its victims. It is not, as is generally believed, the product of genetic determination, randomness, or the absence of logic. It is a conscious and intelligent human activity with a clearly defined purpose that arises from development of certain types of relationships between humans. It is, accordingly, both changing and historic. It is expressed in concrete acts but requires and assumes particular contexts, motives, legalities, and value systems. However, it does not end with the acts themselves, but rather generates new processes and responses, producing individual and collective changes and consequences. More than a process, it is a group of processes. It has roots, purposes, and both immediate and longer-term consequences. It is a language without words, one that is physical and symbolic. Each violent act victimizes, wounds, hurts, or kills-and at the same time symbolically expresses confrontations, power struggles, and the emergence or reaffirmation of forces and purposes.

The Latin American Center for Studies on Violence and Health, one of the organizations that has been examining this subject in Brazil, insists that violence is generated and developed in life as it occurs in society, pointing to its historic specificity and the convergence of problems of a political, economic, moral, legal, psychological, and institutional nature that generate it, even on the individual level. The same group has stressed that violence involves a web of activity in which we are not always victims but may often find ourselves transformed into aggressors (6).

Over the past decade, PAHO has become increasingly interested in the topic and has supported forums for examining how violence as it relates to the health sector can be addressed. Some PAHO documents continue to emphasize the behavioral aspect of violence (7); and, accordingly, proposals for action tend to focus on individual behavior. Obviously, however, PAHO does not maintain a monolithic position in this regard. Studies financed by the Organization or by certain of its contract personnel have contributed to expanding the theoretical horizon, exploring the political aspects of violence, and increasing the information available on the subject $(8-10)$.

The present discourse on the ties between violence and health focuses on the specific case of Colombia. The magnitude of certain forms of violence in that country, such as homicide and kidnapping, and the trends that they reveal make this country an extraordinarily good place to explore such ties. Although a full characterization of the current national reality does not fall within the scope of this work, certain basic points relating to that reality must nonetheless be affirmed.

In the first place, it is necessary to point out that violence is not an exclusive national legacy, that Colombia does not rank highest among countries in terms of most forms of violence, and that there are no specific genetic markers or hormone levels that make Colombians an especially violent human group. To be sure, there are certain relevant cultural elements-some of which have been explored (11-14) while others have not-and a complex array of factors: international relations; lack of equity; exclusion of certain groups from the country's economic and political life; drug trafficking; a number of crises and transitions in terms of ethics and values; political and military conflicts; a dysfunctional justice system; and lack of punishment (15-20).

Colombia's regional, cultural, ethnic, and political diversity is also important. For example, the pronounced differences in family structure and dynamics found in the coastal area as compared to the Andean highlands lend different profiles and intensities to intrafamily violence. Similar differences tend to characterize urban versus rural violence, violence occurring in large versus small cities, and violence found in areas where drug trafficking, guerrilla warfare, or both have had greater or lesser degrees of influence. Any discourse on violence in Colombia must take into account these and other differences.

\section{THE IMPACT OF VIOLENCE UPON HEALTH}

It is not possible to fully describe the relationship between violence and health in Colombia. Not only is the relationship complex, but there is an acute lack of information. In Colombia, as in many other countries, there are problems with the codes and indicators used, events recorded, and coverage and quality of the information systems reporting on violence, both generally and in the health sector. Recognizing these limitations, I have highlighted several aspects of the problem as well as a number of indicators and their respective trends in order to provide an idea of the problem's magnitude and the urgency with which decisions and actions need to be taken.

\section{The homicide epidemic}

Three decades ago violence, responsible for the set of deaths due to "external causes" in the nomenclature of the health sector, ranked ninth among all causes of death in Colombia. In the 1970s it rose to fourth place; and since the 1980s it has ranked first, progressively widening the gap between itself and the other leading causes of death.

However, a more dramatic indicator of the true picture is not the increase in violence per se, but rather the increase in the number of homicides. Over the 
past decade, more than 230000 homicides have been recorded in Colombia, a figure exceeding the 200000 estimated to have occurred in the 1940s and 1950s during the period of La Violencia. According to data provided by the National Institute for Legal Medicine and Forensic Sciences (Instituto Nacional de Medicina Legal y Ciencias Forenses-INMLCF), in 1994 homicides accounted for $70 \%$ of all violent deaths recorded in the country (21). Moreover, data provided by the Ministry of Health (Table 1) indicate that from 1987 to 1994 the homicide rate increased from 36 to 127 per 100000 inhabitants. Other sources, such as Yunes and Rajs (10) (Figure 1), show slightly different rates indicating a similar trend. Irrespective of the precise figures, however, it seems clear that Colombia currently has the highest homicide rate of any country in the world.

Even more alarming than the total number of homicides is their distribution by sex and age. Young menprogressively younger and youngerare the most frequent victims of homicide, although women are not immune. Regarding this latter point, in the 1980s the city of Medellín recorded 18 times more male than female murder victims (22); but in 1994 it recorded a male rate only 13 times greater (21). So even though male predominance was maintained, the relative number of female victims was higher.

Regarding age, according to the INMLCF in 1994 members of the 15-24 year group were victims of $34.2 \%$ of all homicides in the country, while the 25-34 year group accounted for an additional $33.3 \%$. Thus, over twothirds of all homicide victims were between the ages of 15 and 34 (21).

As illustrated in Figure 2, which shows the distribution of homicides in Colombia in 1994 by age and sex, the number of children who were murder victims is also very high. At the beginning of the 1990s, homicide was the second most frequent cause of death among children 5 to 14 years old (23). In this regard, it is worth noting that in Medellín alone, 700 violent deaths were reported among children and
TABLE 1. Homicides per 100000 inhabitants; Colombia, 1987-1994

\begin{tabular}{lc}
\hline Year & $\begin{array}{c}\text { Homicides } \\
\text { per } 100000\end{array}$ \\
\hline 1987 & 36 \\
1988 & 53 \\
1989 & 68 \\
1990 & 73 \\
1991 & 81 \\
1992 & 86 \\
1993 & 106 \\
1994 & 127 \\
Total & 630 \\
\hline
\end{tabular}

Source: Centro de Referencia Nacional sobre Violencia (21).

young people under age 18 during the first eight months of 1995 (24). In Itagüi, one of the 10 cities in the country with the highest numbers of autopsies performed in 1994, homicides were the principal form of violent death for all age groups above 5 years (21).

Data from 1994 also indicate that Colombia's largest cities-Santa Fe de Bogotá, Cali, and Medellín-which together account for a third of the country's total population, had $50 \%$ of all recorded homicides. These figures support the idea that the violence cur-
FIGURE 1. Mortality per 100000 from homicide, traffic accidents, and suicide in Colombia, 1984-1990

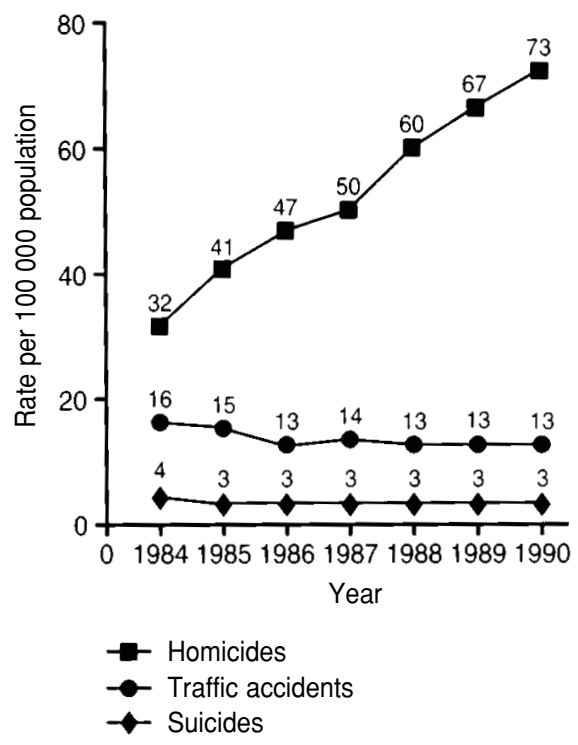

Source: Yunes J, Rajs D (10).

rently plaguing the country has been urbanized, a phenomenon that distinguishes it from the classic violence referred to earlier (25). According to data provided by the National Police Force, in $199085 \%$ of the reported

\section{FIGURE 2. Homicides by age and sex in Colombia, 1994}

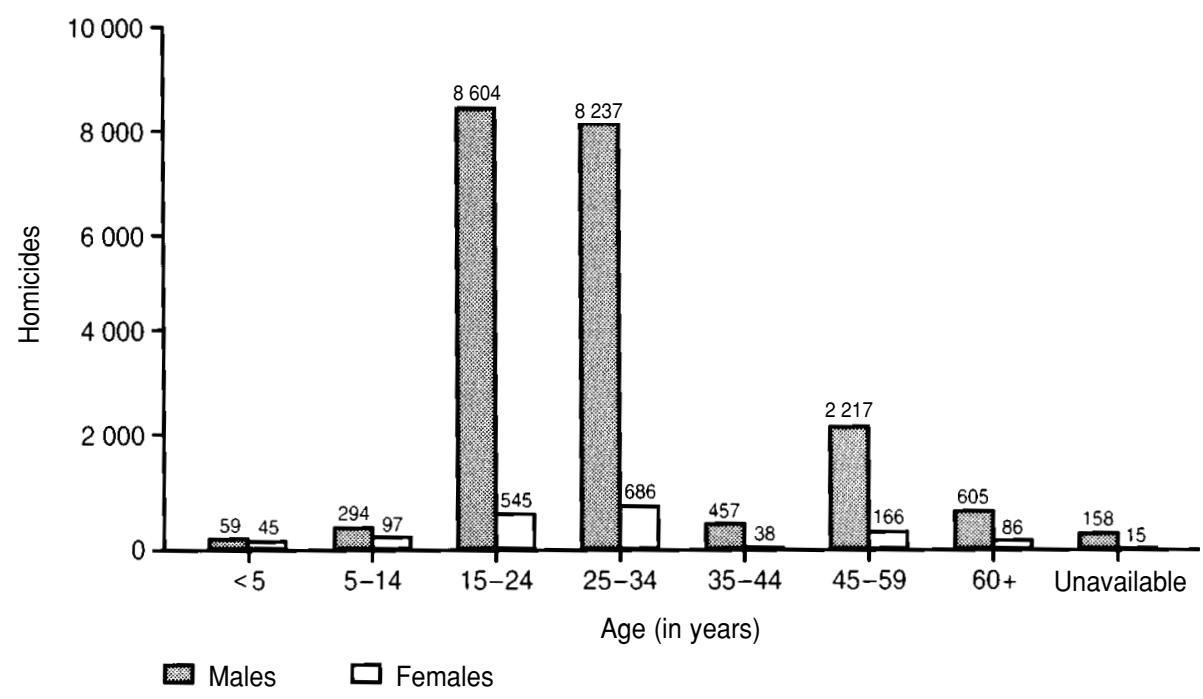

Source: Centro de Referencia Nacional sobre Violencia (21). 
crimes against property and $78 \%$ of those involving death or bodily injury were committed in urban areas (26). Although the current pattern clearly indicates that violence has been urbanized, that does not mean rural violence has been eliminated. In the predominantly rural department of Guaviare, for example, a 1994 report cites homicides as accounting for $61 \%$ of all deaths (23).

Based on perhaps questionable logic, the category "external causes" of death includes traffic accidents as well as suicides and homicides. Although an indeterminate percentage of traffic accidents may reflect the type of violence described above, a large but unquantifiable percentage reflects accidental phenomena involving neither intent nor premeditation. By disaggregating the "external causes" of death in Colombia into their three principal components (homicides, traffic accidents, and suicides) and observing their respective trends over a period of seven consecutive years, it has been confirmed that homicides have shown a marked increase, while traffic accidents and suicides have remained at low, relatively stable levels (see Figure 1).

In 1984 two homicides were recorded for every traffic accident death and eight for every suicide. According to INMLCF figures, 10 years later, in 1994, homicides were four times more frequent than deaths from both other causes combined. Within this context, it is perhaps noteworthy that people between the ages of 14 and 34 account for $60 \%$ of all suicides, with men accounting for four out of five. In the department of Antioquia, where homicides have shown a dramatic upward trend since 1984, deaths from automobile accidents have shown a sustained downward trend since 1985, while the suicide rate has remained consistently low (27).

A wealth of data have been obtained that describe the socioeconomic status of Colombia's victims of violence. In particular, a study conducted by the Ministry of Health and published in 1993 (28) showed that traffic accident deaths were distributed almost uni- formly throughout all socioeconomic levels, while the frequency of suicides increased gradually with increasing socioeconomic status and the frequency of homicides increased with decreasing socioeconomic status.

The magnitude of the violence problem in Colombia can best be appreciated by making comparisons with other countries. In the Americas, for example, Colombia ranks first in terms of death from all violent causes. According to figures provided by $\mathrm{PAHO}^{3}$ in 1990 the registered crude mortality rate from all violent causes was 76 deaths per 100000 inhabitants, followed by Puerto Rico with 27 per 100 000. Homicide figures were even more striking. According to the same source, in 1990 Colombia headed the list for the Americas with a rate of 73 homicides per 100000 inhabitants, while Canada (2 homicides per $100000)$ had the lowest rate. In contrast, Colombian mortality from accidents and suicides was intermediate. In 1990 Canada recorded the highest suicide rate, 13 deaths per 100000 inhabitants, while Colombia had a rate of 3 per 100000 . In 1989, Chile recorded the highest accident mortality, 66 deaths per 100000 inhabitants, while in the following year Colombia recorded only 39 per 100000.

Overall, Colombia currently accounts for approximately $15 \%$ of all violent deaths and $20 \%$ of all homicides in Latin America and the Caribbean. When homicides for Colombia and the United States are compared, the contrast is alarming. From 1984 to 1989, the United States recorded a peak homicide rate in the 10-24 year group of 12 deaths per 100000 inhabitants, while in Colombia the rate for this age group was 63 deaths per 100000 in 1989 and 75 per 100000 in 1990 (Figure 3). The difference was even greater in the 20-24 age group. In 1989 the United States had a rate of 19 homicides per 100000 population in that age group, which is unacceptably

\footnotetext{
3 Data from PAHO Technical Information System.
}

FIGURE 3. Mortality per 100000 from homicide in the 10-24-year age group in Colombia and the United States, 1984-1990

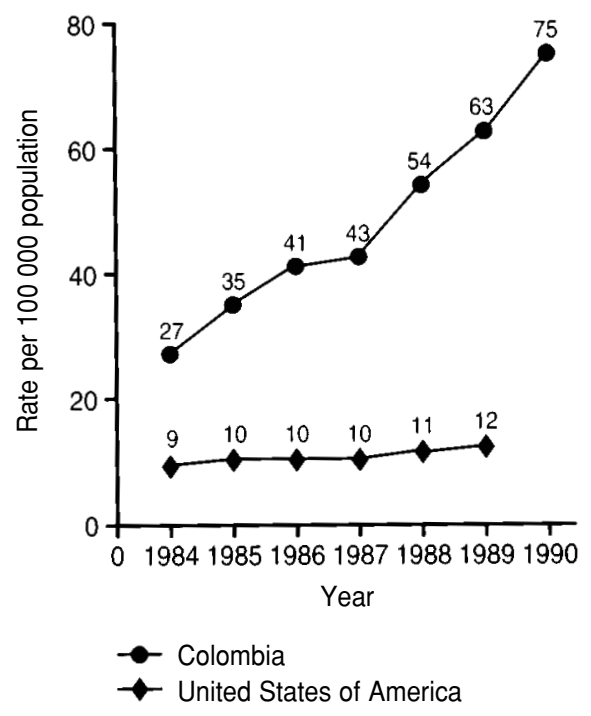

Source: Yunes J, Rajs D (10).

high for a developed country, while the rate in Colombia in the same year was 126 per 100000 -six times higher than the rate in the United States.

In view of the above, it is no exaggeration to say that Colombia suffers from a veritable epidemic of homicides. Indeed, this would seem belated recognition of an important national reality. Violence is not only epidemic but currently constitutes the country's primary public health problem, in terms not only of death but also of suffering, illness, reduced quality of life, and economic costs for both society and the health sector.

To illustrate this latter point, consider the AIDS problem. The importance of AIDS is obvious, and concern over its spread is understandable; but since the disease was described more than a decade ago, the number of Colombians who have died of AIDS has not yet reached 10 000. In contrast, over a shorter period more than 230000 Colombians have been murdered. All in all, what is important is not designating the violence in epidemiologic terms nor agreeing on assignment of priorities, but rather recognizing the violence problem, 
making a political decision to confront it, and converting that decision into sustained action.

\section{The daily nature of violence in Colombia}

Violence as a mechanism for resolving conflicts has deeply pervaded the myriad social strata, scenarios, and relationships existing in Colombia. Indeed, its persistence and intensity have given it a certain semblance of normalcy. One can even go so far as to say that we are beginning to live within a violent order (5), i.e., that types of relationships characterized essentially by mechanisms of force, coercion, and fear have been imposed. This is not to imply that violent acts occur only in Colombia, or that violence is the only form of interaction between Colombian individuals and institutions, or between citizens and the government. But it does imply a relative predominance and acceptance of violent actions over all other possible types of relationships, and an almost inevitable daily contact, in the most intimate of individual and collective experiences, with the consequences of violence. Such contact is experienced on a daily basis in the home, at work, at school, at sporting events, and in the street.

According to data provided by the INMLCF and organizations working to prevent kidnapping, during 1994 Colombia recorded a daily average of 73 homicides, 4 suicides, and 4 kidnappings (21). In addition, the pervasive predilection toward violence was contributing to the hundreds of daily cases of intrafamily violence, scores of sex offenses, and various other human rights violations-including denial of the right to work, the right to study, and the right to health. Resolution of the most insignificant differences involving conflicting interests, opinions, tastes, or amorous pursuits is sought through resort to force. Whether people are dealing with a traffic violation, an athletic victory or defeat, a dispute between neighbors, a small debt, or a judicial proceeding, violence tends to be the most immediate and definitive option.

One form of violence that has recently been the subject of special attention is intrafamily violence. Meetings have been held on this subject, research findings have been compiled and published, and response mechanisms such as the Prevention Networks (29-31) have been created. Of course, it is no longer possible to speak of the family as a unit consisting of a father, a mother, children, and other relatives. Today the family has a broader profile and may best be characterized as a series of relationships mediated by blood ties that has multiple and changing forms. As a daily scenario for affection, power, passion, and personal differences, it is a potential source of violence.

Due to the complex everyday nature of family relationships and the duality of public and private life, there is little doubt that the recorded incidents of intrafamily violence are but a small percentage of those actually taking place. Despite this, and despite the fact that the INMLCF handles only the most serious cases with criminal implications, during 1994 it handled a daily average of 93 cases of intrafamily violence, of which $75 \%$ dealt with marital problems and 13\% with child abuse. Out of every 21 victims of conjugal mistreatment, 20 were women (21).

According to a survey conducted in Colombia (32), one out of every three women living with her partner had been insulted, one out of every five had been beaten, and one out of every ten had been raped. Also, the previously mentioned study conducted by the Ministry of Health (28) found verbal abuse of women to be frequent in all social strata, while physical abuse appeared more frequent in lower strata.

Child abuse also deserves special attention. We have already noted the growing childhood mortality due to violence. To cite two more examples, in the first half of $1994,6 \%$ of all homicides committed in the city of Medellín killed children (defined as those under age 15). Of the average 18 homicides committed daily in Santa Fe de
Bogotá, four victimized children; that is, in Santa Fe de Bogotá alone there is an average of one child murdered every 6 hours.

According to a survey conducted by the Colombian Institute for Family Welfare, fully a quarter of all children in Santa Fe de Bogotá have been mistreated by their parents. Both physical and verbal mistreatment appear to be more frequent in the middle and lower socioeconomic strata, while girls tend to be the primary victims of sexual violence.

In 1994 the INMLCF handed down a daily average of 30 judgments involving sex crimes. In the first quarter of 1995, this figure was $8 \%$ higher than the figure for the same quarter in the preceding year. Sixty percent of these judgments involved cases of violence committed against children under the age of 14 , with the ratio of female to male children involved being 10 to one (33). Other frequent types of child abuse include abandonment, neglect, forced labor, forced displacement (with its consequent cultural uprooting, family disintegration, and economic disruption), and creation of orphans (34).

Boys and girls are not always the victims of webs of violence. They can also be-and increasingly are-the aggressors. In 1993, 14461 new judicial child delinquency case files were opened; only two years later, in 1995, that figure had risen to over 35000 . The ranks of organized guerrillas, hired killers, and both organized and unorganized crime continue to swell with increasingly young children. The participation of such children ranges from support and complicity to direct responsibility for commission of crimes, including homicide. Reliable information indicates that children participated in recent massacres at Urabá. The subject has generated considerable interest and is cause for great concern because of its implications for the future.

Obviously, the subject of childhood violence also involves many other issues: the current family structure crisis; violence that is experienced in infancy and reproduced in adulthood; 
the lack of social equity; the style and content of formal and informal education; the media's role in information dissemination and breakdown of the social conscience and social values; ethical foundations; and punishment and rehabilitation of delinquent children. Rather than being of mere analytic interest, however, the problem should evoke a social response-that is, if we are truly to set the stage for a less violent future, not only in the political and social arenas but in daily life.

The daily occurrence of pervasive violence also leads to a sort of trivialization of violence; i.e., to its acceptance as an unimportant phenomenon. Tolerance of violence increases, individual and collective response mechanisms are reduced, the capacity for astonishment is lost, and people succumb to fear and indifference. This trivialization adds a new dimension to the problem and promotes a certain fatalism, with perverse consequences when a decision is made to try and activate response mechanisms.

\section{"Expendables," murder for hire, and massacres}

These three phenomena are a daily part of violence in Colombia and highly illustrative of the current picture. Although none is an exclusively national invention or legacy, over the past decade all three have become increasingly common. Therefore, briefly describing them tends to bring out implications of the current violence, point up the seriousness of its continued presence, and encourage countermeasures. It also demonstrates the impossibility of classifying as "healthy" a country or society that generates massacres, encourages murder for hire, and produces and eliminates "expendables."

The term "expendable," which has its roots in the industrial world, referred originally to products and articles to be disposed of after they reached the end of their useful life. The concept was applied to people beginning with what Hanna Arendt decades ago called "superfluous populations," whose nature is still being explored in Brazil by several researchers (35). In Colombia the term refers not to a homogeneous group but rather to diverse groups having the same quality-that of being unnecessary, undesirable, and nonfunctional-by reason of which they should be eliminated. For some, an "expendable" is a person engaging in deviant sexual behavior (such as a prostitute, transvestite, or homosexual); for others, it may be a street thief, a political opponent, a business or love rival, a beggar, a handicapped person, someone of another race, etc.

With regard to extermination of "expendables," the social sectors classifying them as such not only take a permissive stance but actively encourage such extermination. If killing is the customary way to attempt to resolve a conflict, killing the "expendable" constitutes a task of "social cleansing," a concept used to justify the extermination of many "expendables."

Regarding murder for hire, the real problem is partly the existence of hired killers but more fundamentally acceptance of the murder for hire concept. After all, paid killers are merely the end points of complex circuits, the external faces of hidden actors. The fact that such hired guns exist is serious enough, but even more serious is the fact that murder for hire exists; it is bad enough that someone kills because they are paid to do so; but it is even worse that someone would pay to have another killed. Both phenomena are based on the same principle: It is all right to hire and pay someone a price in money for eliminating another's life. But while the hired assassins go about their business with no aim other than pecuniary remuneration, the true protagonists of murder for hire are those who, because of their own values and interests, select the victim, put a price on his or her head, provide the money, and contract the deed. This entire process of murder for hire categorically rejects any type of legal order, the nonnegotiable nature of human life, and various essential roles assigned to the State and civic relations.

It is striking that in Colombia, where murder for hire has reached alarming proportions, so little progress has been made in understanding its roots, disentangling its networks, and identifying its representatives. This may be due to its ties to the complex and dangerous world of drug trafficking; but to overcome the current levels of violence, it is necessary, among other things, to understand the phenomenon of murder for hire and to proceed to combat it.

Massacres are collective and simultaneous murders. Their occurrence in Colombia has increased considerably over the past decade, and they tend to be concentrated seasonally in particular areas. According to the country's principal newspapers, during the first 10 months of 1994 the valley of Aburrá, where the city of Medellín is located, was the site of 43 massacres claiming a total of 179 lives, there being an average of four deaths per massacre, mostly young men. In August and September of 1995, massacres were concentrated in the banana-producing region of Urabá, where eight massacres causing 91 deaths, an average of 11 deaths per episode, were recorded.

The municipality of Apartadó in the latter region also experienced one of the worst massacres in the country's recent history in January 1994. This incident produced 36 dead and 17 wounded, all of them residents of a squatter community, many of whom had rejoined civilian life following association with a guerrilla group.

Massacres are not always directed toward the same targets. Some seek to eliminate a particular type of expendable, while others seek to liquidate pending accounts between drug or arms traffickers, eliminate political rivals or opponents, make a show of force and dominance in a particular region, or terrorize anyone daring to express dissent. There are even wellfounded indications that some massacres have been the final "test" in a training process designed to produce hired assassins. In all cases, such collective murder has a symbolic and intimidating effect. Massacres demonstrate the vulnerability of society, the ability of certain individuals or groups to contravene any elementary stan- 
dard or concept of coexistence, the loss of the State's monopoly on power, and the extent to which human life has currently been devalued. In addition, as a result of the internal dynamics of the phenomenon, many massacres have occurred in response to preceding massacres, thus leading to a sort of perverse cycle of mass murder. All this indicates that massacres, as deeds of collective violence, demand actions and reactions that are also collective in order to reduce their legitimacy and help to control or eliminate the factors responsible for their occurrence.

\section{THE COSTS OF VIOLENCE FOR THE HEALTH SECTOR}

Whether from an economic, social, emotional, or psychological perspective, the costs of violence for the Colombian health sector are very high. As defined here, "health costs" are considered to include (1) goods, resources, and funds devoted to maintaining health care and recovery services that are lost as a result of the damage done by violence; and (2) the negative impact that the prevailing violence has on the quality of individual and collective life. The topic obviously demands greater conceptual precision, as well as direct in-depth investigation. For purposes of this study, however, it should suffice to point out a number of indicators that accurately reflect the towering costs of violence for both the country's health and its health system.

Several groups, using various methodologies, have studied aspects of violence and its health implications in a number of countries and subregions (36-41). As a rule, the studies involved are local, sectoral, or regional ones whose methodologies do not permit estimation of the overall costs of violence or accurate definition of many issues considered here to be important. The most commonly used indicators have been the previously mentioned rates of morbidity and mortality from external causes; years of potential life lost; percentage of mortality attributable to external causes; percentage of hospital beds and days of hospital stay devoted to victims of violence; and the direct costs of medical and hospital care for such victims.

Several researchers and institutions have recently begun to use the indicator known as "years of healthy life lost," which is equivalent to healthy years lost not only to premature death but also to disability. Information is perhaps least available regarding deterioration in the quality of life from specific causes, and it is accordingly this subject that requires the greatest future work.

Of the studies cited, one especially interesting report that includes partial data for Brazil, Mexico, and Peru was sponsored by PAHO's Division of Health Promotion and Protection (41). The data cited for each country are based on limited case studies that explore only the costs of hospital care using diverse methodologies, universes, and periods. The studies conducted in Mexico and Peru, for example, were based on data collected by one service within a single hospital by means of a one-week survey. Using this limited data base, the authors conducted prospective analyses for all countries of Latin America and the Caribbean; they concluded that within this region the cost of care provided to $50 \%$ of the victims who died and $100 \%$ of those suffering mild to severe injuries was between US\$3600 million and US\$ 5600 million, an amount equivalent to between $4 \%$ and $7 \%$ of all health expenditures by all the countries involved. In these same countries, the economic losses arising from premature death and disability caused by violence were estimated at US\$11400 million.

In Colombia, homicides and accidents are the primary cause of years of potential life lost. In 1991 they accounted for $39.9 \%$ of the total years of potential life lost, while perinatal causes ranked second, with $13.3 \%$ (42). According to the same source, in the decade between 1983 and 1992 the percentage of years of potential life lost from causes related to violence and accidents exhibited an upward trend.
If we begin with the premise that the current life expectancy at birth of a typical Colombian is 69 years and that the average age of homicide victims is 29 , it can be deduced that for each murder an average of 40 years of potential life are lost. If we estimate the annual number of homicides at approximately 30000 , it appears that the country annually loses some 1200000 years of potential life from this cause.

While in 1983 violence and accidents accounted for $17 \%$ of all deaths in the country, as of 1991 that percentage had increased to $27 \%$. This implies that of every four Colombians who died in 1991, one died as a result of an accident or violence.

In Antioquia, which has accounted for a high percentage of all homicides, the number of years of potential life lost from this cause in 1982 was estimated at 64833 , equivalent to $20 \%$ of the total number of years of potential life lost. In 1992, the absolute figure had increased to 507200 years and the corresponding percentage to an astounding $84 \%$ (27).

With regard to the so-called "burden of disease," as estimated in terms of years of healthy life lost, homicides ranked first. In the period from 1989 to 1991, homicides accounted for 1356675 years of healthy life lost, or $24.6 \%$ of the national total, a percentage twice as high as that attributable to cardiovascular diseases (43). If it were not for violence, the average life expectancy of Colombians would be greater that the current level of 69 years. This is confirmed by the widely substantiated fact that life expectancy for females exceeds that for males and that the gap between relative longevity of males and females is increasing.

With regard to monetary costs, the figures are still incomplete, unreliable, or excessively general, and are based on units that remain controversial. However, efforts to estimate such costs are being made. One study conducted by the National Department of Planning and reported in a national economic publication (44) recently presented a number of figures relating to the total cost of violence in Colom- 
bia. According to the report, every year the country spends Col\$ 6200 million as a result of violence. This total was obtained by adding the amounts spent on defense, public and private security, justice, and kidnap ransoms; the cost of crimes against public and private property; and the estimated monetary damage done by homicides in terms of years of potential life lost. No estimate was made of the health sector's share of these costs; and although the figure given sheds light on the magnitude of the problem, it includes some items that are too broad while excluding others that are essential, and so its accuracy appears questionable.

In 1993 Colombia's Minister of Health estimated the average cost of caring for a trauma case at Col\$ 600000 (US\$ $1.00 \approx \operatorname{Col} \$ 1000$ ) and the annual cost of caring for all cases of violence and trauma in the country at Col\$ 80000 million.

That same year the Director of the San Vicente de Paúl University Hospital in Medellín, a facility where a quarter of the available beds were then used to treat severe violence cases and a third of all expenditures were for personal injury cases, estimated the hospital's annual cost of caring for trauma cases at Col\$ 5340 million, this being equivalent to an average daily cost of Col\$ 15 million. In 1990, a third of the hospital's total budget went to pay hospitalization costs resulting from personal injury (39). In 1994 the same hospital's adult emergency room admitted a monthly average of 1268 trauma/violence cases. If one uses the above estimated national average cost of caring for each case (Col\$ 600 000), the approximate annual cost at this facility in 1994 was Col\$ 9120 million. Who pays such costs, projected at the national level?

Other costs that have not been accurately estimated include the cost of organic, mental, and physical consequences of violent acts not leading to death, as well as the cost of other indirect consequences of such acts. Examples of such costs include loss or crippling of extremities or organs; changes in psychological, affective, intellectual, or motor development or function; and reduction of sensory or perceptive acuity. No less great are the costs of rehabilitating recoverable functions and the costs of providing the legal and forensic medical services essential for legal decision-making and criminal prosecution-which include the costs of keeping up with scientific and technical developments in forensic medicine.

It is possible that the greatest costs of violence cannot be estimated in quantitative economic terms. Who can estimate the cost to a child of becoming an orphan or the cost to an adult of losing a spouse? How can we evaluate the impact of a massacre upon the victims' relatives, neighbors, colleagues, and friends, or upon the local population as a whole? How many units of continuous pain and suffering are equivalent to the permanent loss of a friend or family member? And how can we estimate in terms of individual and group welfare the costs of displacement and forced exile as a result of threatened or actual violence? Obviously, it is not possible to enjoy life or even to sleep, work, and eat the same following the murder or disappearance of a son or daughter, relative or friend.

As this suggests, mental health consequences are an important result of violence suffered either directly or indirectly-as are changes in blood pressure, the integrity of the gastrointestinal tract, and brain function. It is possible that Colombians' daily allotment of laughter has decreased noticeably over the past decade, due in large part to the extreme violence they have experienced. In this same vein, there is evidence, which needs to be rigorously assessed, that both medical consultations and consumption of drugs to combat depression, gastritis, headache, and insomnia are on the rise.

\section{RESPONSE OF THE HEALTH SECTOR TO VIOLENCE}

Neither the health sector as a whole nor its individual components, with their sometimes extreme resource limitations, normally receive recognition for their daily response to the care needs of violence victims. There are many untold stories of helpfulness, solidarity, and heroism in this field.

The purpose of this final section is to identify the various areas where the health sector, in collaboration with other sectors, can help combat the violence problem and find alternatives by which the citizenry can achieve a status of healthy coexistence. An initial premise is that the Colombian health sector and its various institutions are still responding insufficiently and inadequately to the violence problem because of that problem's size, dynamics, and progressive growth.

Two observations are critical. First, it is important to note that the health sector, rather than helping to address and eliminate violence, frequently generates more violence. Structurally, the lack of health coverage for almost a third of Colombia's total population is in itself a significant sort of neglect that encourages and sometimes itself borders on violence. In addition, when the sector, through any of its agents, rigidly imposes standards or decisions or attempts to nullify significant elements of the patient's subjective identity, it may openly violate human rights and commit consequent acts of violence. Frequent examples include the practice of certain procedures on women who have been victims of rape or the admission of a patient against his or her will.

Second, we tend to underestimate the problem of violence. That is, the conceptual base of health work, the mechanisms of professional practice, and the assimilation and appropriation of particular social functions frequently lead us to compartmentalize medical practice and knowledge, and indeed to regard violence in this manner. For this reason, we end up being unaware of the nature, magnitude, and dynamics of the particular problem-which lessens the health sector's potential contribution and aggravates the subdivision of knowledge and failure to come to grips with the issue.

In principle, it is possible to distinguish three types of health sector institutions that are necessarily associated 
with the violence problem and from which society has a right to demand a better response and increased collaboration. These are the institutions in charge of preparing health personnel; those responsible for caring for and rehabilitating victims of violence; and those charged with activities involving orientation, management, financing, and evaluation.

If we examine the subject matter included in the curricula of technicians, auxiliaries, physicians, and other health workers, as well as their areas of practice, lines of research, cultivated skills, and hours devoted to the subject of violence, one can see an enormous contrast between the magnitude of the violence problem in Colombia and the importance accorded to it. Clearly, the time has come for a more organic, effective, and permanent integration of the various facets of the subject within the various stages of the educational process. If the problem's social magnitude is going to be reflected in the interests, substance, and daily activities of academic life, then violence (as a subject for study and transformation, as well as for confrontation as a social responsibility) must have a greater presence within the subject matter included in the educational cycle and must elicit increased intellectual effort and greater creativity in designing response strategies, mechanisms, and actions.

With regard to the tendency to compartmentalize cited above, schools must take care to avoid "medicalizing" violence-i.e., reducing it to "bionatural" logic and attempting to address it using the resources and disciplines traditionally employed by the various health professions. As a result of the nature, dynamics, meanings, and implications of violence, understanding and managing it requires an intersectoral, interdisciplinary, multiprofessional, and participatory effort. It will be necessary to overcome ignorance and prejudice in the areas of economics and law, sociology and ethics, history and philosophy. It will be necessary to journey into other settings, beyond doctor's offices and hospitals, to listen to nonpatient interlocutors, associate with new actors, and open new fields of work.

As part of the national academic community, researchers have played an important role in clarifying the problem of violence in Colombia. Nevertheless, so great is the gap between social needs and scientific priorities that there is still much to be done. Epidemiology as well as legal medicine and forensic science, epidemiologic surveillance as well as ultramodern information systems, and knowledge of the social, medical, and physiopathologic bases of violence and trauma should all be enlisted and supported by a powerful surge of scientific development in Colombia. In terms of scientifically comprehending the problem and creating social awareness of it, the academic world has an obligation to the country to complete the unfinished task at hand.

Welfare services have paid a very high price in caring for those suffering the worst consequences of violence. It has been their employees who have had to deal with the pressure of the crisis and the despair of the victims and their families. The organizations themselves have had to sharply augment their generally scarce resources in order to satisfy a tremendous demand.

It must also be recognized, however, that the response has often been passive and the resources insufficient visà-vis the nature, dynamics, and magnitude of the problem. Given trained personnel with insufficient vision and preparation to understand and deal with the problem, and given services designed for specific forms and types of care that are structurally limited by acute deficiencies, the health sector's ability to meet the demands imposed by violence is still precarious. The problem requires psychological understanding; a multidisciplinary rapid response team working through a coordinated network; streamlined intervention and referral mechanisms; adequate supplies, equipment, and facilities; a systematic care framework; and permanent evaluation and adjustment mechanisms.

Beyond this, institutions should devote themselves directly, without sacrificing their health care responsibility, to supporting and intensifying preventive actions, to promoting health and to protecting life. These activities require actions by multiple sectors, additional resources, and a capacity to create new relationships and run new risks.

Obviously, although health care services are unable to solve the problem, they can still play an important role in combating one of its fundamental aspects. Such services would make a much greater contribution to mitigating the impact of violence-monetary costs, human suffering, lost lives, etc.-if a focus on violence proportional to the problem's magnitude were part of their orientation, funding, structure, and function.

A similar statement can be made about entities and institutions devoted to health sector policy formulation and decision-making, as well as financing, programming, management, and evaluation. One should not seek to restructure everything as a function of violence, but current ignorance and underestimation of the problem are both counterproductive and extremely expensive. It is not possible to address in a marginal or symptomatic way (or what is worse in a politically opportunistic manner) a problem that is responsible for a quarter of all deaths and a third of the services provided by the health system. In this vein, it behooves us to note the value of international cooperation, the importance of addressing the problem from an intersectoral and interinstitutional standpoint, and the need to coordinate national policies and plans with those of other countries in order to better implement potential initiatives and resources.

In a recent article I proposed that the scientific and political efforts of the international medical-social community be coordinated with a view toward designing and putting into effect a life-promoting agenda (45). If violence constitutes the primary threat to life and well-being in Colombia today, then there is even more reason, in combating it, to go beyond individual and sectoral actions and interventions 
to coordinate all of the efforts of the public health and epidemiology sectors, in an attempt to put into play a large-scale mobilization in defense of the right to life and health. This implies having well-defined policies and general options at the individual and collective levels; reaching a series of intra- and interinstitutional agree- ments at the local, departmental, and national levels; assigning priority to certain factors, tasks, resources, and mechanisms; and enlisting the active support of the media. In addition to their power of convocation and their ability to put an end to the apathy and tolerance of violence, the lifepromoting agenda and the pro-health movement have the ability to become concrete mechanisms for civic participation and vehicles for reformulating government action and strengthening civil society. All of these are essential mechanisms for reversing within a reasonable time frame the intolerable spiral of violence currently plaguing Colombia.

\section{REFERENCES}

1. Guzmán CG, Umaña LE, Fals-Borda O. La violencia en Colombia: monografías sociológicas. Santa Fe de Bogotá: Universidad Nacional; 1962.

2. Bejarano J, Fals-Borda O, Fajardo D, et al. Once ensayos sobre La Violencia. Santa Fe de Bogotá: Centro de Estudios de la Realidad Colombiana, Centro Gaitán; 1985.

3. Comisión de Estudios sobre la Violencia. Colombia: violencia y democracia. Santa Fe de Bogotá: Universidad Nacional de Colombia, Instituto Colombiano para el Desarrollo de la Ciencia y la Tecnología Francisco José de Caldas; 1989.

4. Franco S. Violencia y salud. Rev Universidad Antioquia 1990;220:18-27.

5. Franco S. Violencia, ciudadanía y salud pública. Santa Fe de Bogotá: Corporación Salud y Desarrollo; 1995. (Special Documents Series, No. 4).

6. Minayo MC. A violencia social sob a perspectiva de saúde pública. Cad Saude Publica 1994;10(suppl 1):7-19.

7. Pan American Health Organization. Resolution XIX: Violence and Health. In: Final Report of the XXXVII Meeting of the Directing Council of PAHO. Washington, DC: PAHO; 1993. (Document CD37/FR).

8. Franco S. La violencia: un problema de salud pública que se agrava en la Región. Bol Epidemiol OPS 1990;11:1-7.

9. Camacho GA. Dimensiones de la democracia y la violencia en las Américas. Washington, DC: Organización Panamericana de la Salud; 1994. (Document PAHO/HPP/94.23.)

10. Yunes J, Rajs D. Tendencias de la mortalidad por causas violentas en la población general y entre los adolescentes y jóvenes de la Región de las Américas. Cad Saude Publica 1994;10 (suppl 1):88-125.

11. Fals-Borda O. Lo sacro y lo violento: aspectos problemáticos del desarrollo en Colombia. In: Bejarano J, Fals-Borda O, Fajardo D, et al. Once ensayos sobre La Violencia. Santa Fe de Bogotá: Centro de Estudios de la Realidad Colombiana, Centro Gaitán; 1985.

12. Perea-R CM. Porque la sangre es espíritu: imaginario y discurso político en las élites capitalinas. Santa Fe de Bogotá: Instituto Colombiano de Bienestar Familiar; 1995.

13. Restrepo LC. Democracia vivencial y cultura de la convivencia. Rev NOMADAS (Santa Fe de Bogota) 1995;2:60-67.
14. Salazar A. No nacimos pa'semilla. Santa Fe de Bogotá: Centro de Investigación y Educación Popular, Corporación Región; 1990.

15. Camacho-G A. La Violencia en Colombia: elementos para su interpretación. Rev Foro (Santa Fe de Bogota) 1988;6:3-12.

16. Camacho-G A. Cinco tesis sobre narcotráfico y violencia en Colombia. Rev Foro (Santa Fe de Bogota) 1991;15:65-73.

17. Deas M, Gaitán-D F. Dos ensayos especulativos sobre la violencia en Colombia. Santa Fe de Bogotá: Tercer Mundo Editores; 1995.

18. De Roux F. Fundamentos para una ética ciudadana. In: Colombia: una casa para todos; debate ético. Santa Fe de Bogotá: Programa por la Paz, Compañía de Jesús; 1991.

19. Kalmanovitz S. Economía de la violencia. Rev Foro (Santa Fe de Bogota) 1988;6:13-24.

20. Richani I. La economía política de la violencia: el sistema de guerra en Colombia. Santa Fe de Bogotá: Instituto de Estudios Políticos y Relaciones Internacionales; 1995. (Mime graphed).

21. Centro de Referencia Nacional sobre Violencia. Reporte del comportamiento de lesiones fatales y no fatales en Colombia, 1994. Santa Fe de Bogotá: Instituto Nacional de Medicina Legal y Ciencias Forenses; 1995.

22. García H, Vélez C. Muerte violenta por homicidio en Medellín en la década del 80. [Masters thesis.] Medellín: Facultad Nacional de Salud Pública; 1992.

23. Arbeláez MP, Ruiz IC. Vigilancia epidemiológica: indicadores y mapeo de riesgo. Santa Fe de Bogotá: Ministerio de Salud de Colombia y Organización Panamericana de la Salud; 1994.

24. Iglesia denuncia exterminio de la niñez. El Tiempo. Santa Fe de Bogotá, 30 September 1995:15A.

25. Colombia, Ministerio de Justicia y del Derecho. La violencia urbana en Colombia: evidencia empírica y propuestas de política. Santa Fe de Bogotá: Misión Siglo XXI; 1994.

26. Colombia, Policía Nacional. Criminalidad 1990: tendencias de la criminalidad, 1958-1991. Santa Fe de Bogotá: Policía Nacional; 1990.

27. Dirección Seccional de Salud de Antioquia, Oficina de Epidemiología. Series Cronológicas de Salud. Medellín: DSS; 1994.

28. Colombia, Ministerio de Salud. Salud mental y consumo de sustancias sicoactivas. Santa Fe de Bogotá: MINSA; 1993.
29. Redes de Prevención de Violencia Intrafamiliar, Subsecretaría de la Mujer, Instituto Colombiano de Bienestar Familiar. Violencia intrafamiliar: memorias. Medellín: Litoarte 1993.

30. Servicio Seccional de Salud de Antioquia. Violencia intrafamiliar: cotidianidad oculta. Medellín: SSSA; 1994.

31. Universidad de Antioquia, Subsecretaría para la Mujer, Despacho de la Gobernación de Antioquia. La violencia: un problema de la vida de familia. Medellín: Universidad de Antioquia; 1995.

32. Profamilia. Encuesta de prevalencia, demografía y salud, 1990. Santa Fe de Bogotá: ProfamiliaDHS; June 1990.

33. Centro de Referencia Nacional sobre Violencia, Instituto Nacional de Medicina Legal. Delitos sexuales en Colombia, 1994 y primer trimestre de 1995. Boletín del CRNV (Santa Fe de Bogotá) 1995;1:2-3.

34. Gaylin N, Sadlier K, Salas-S M. The effects of chronic community violence on Colombian children and their families. Final report presented to the Pan American Health Organization, Washington, D.C., September 1994.

35. Cruz-Neto O, Minayo MC. Extermínio: violentação e banalização da vida: o impacto da violencia social sobre a saúde. Cad Saude Publica 1994;10(suppl 1):199-212.

36. Hospital Universitario San Vicente de Paúl. Análisis de las condiciones de rehabilitación en Antioquia: su relación con causas violentas. Medellín: Universidad de Antioquia; 1987. (Mimeographed).

37. Médici A. As raizes económicas da violencia e seus impactos na saúde. Paper presented to the Working Group on Violence and Health in Latin America, Río de Janeiro, 11-14 December 1989. (Mimeographed.)

38. De Mello J, De Mello MH. O impacto da violencia nos serviços de saúde. Paper presented to the Working Group on Violence and Health in Latin America, Río de Janeiro, 11-14 December 1989. (Mimeographed.)

39. Cano-G E, Castrillón-Z MT. Egresos por lesiones personales, 1989. Medellín: Fundación Hospitalaria San Vicente de Paúl; 1990.

40. Mondragon D. Hospital costs of societal violence. Med Care 1991;30:453-460.

41. Organización Panamericana de la Salud. El impacto económico de la violencia sobre las instituciones de salud en países de América Latina y el 
Caribe: informe preliminar. Washington, DC: OPS; 1994.

42. Colombia, Ministerio de Salud. La salud en Colombia: diez años de información. Santa Fe de Bogotá: MINSA; 1994.

43. Colombia, Ministerio de Salud. La carga de la enfermedad en Colombia. Santa Fe de Bogotá: MINSA; 1994.
44. Ardila Durán E, Pereira Romero E. La industria de la violencia. Portafolio: semanario de economía y negocios (Santa Fe de Bogotá) 1995; 107:14-16.

45. Franco S. La salud al final del milenio. Análisis político 1995;24:51-64.
Manuscript received on 18 December 1995. Revised version accepted for publication on 20 June 1996.

RESUMEN La violencia en Colombia parece incontenible. A las masacres y asesinatos colectivos, de una crueldad desconcertante, se suman los secuestros y desapariciones, el maltrato de niños y ancianos y las violaciones de adolescentes. Cada día, sin tregua, los colom-

Violencia y salud en Colombia bianos son espectadores o víctimas de atracos callejeros y de discriminación racial, sexual y socioeconómica. Sin quererlo, se convierten en agentes de agresiones en el transporte urbano, el hogar, la escuela y el trabajo.

Colombia tiene las tasas de mortalidad por homicidio más altas del mundo. Independientemente de la enorme sobrecarga institucional que impone a los servicios de salud y medicina legal, la violencia constituye actualmente en Colombia el principal problema de salud pública. Para hacerle frente, el sector de la salud debe elaborar políticas y financiar acciones; crear nuevos procesos de formación de personal, poner en marcha procesos de educación pública y dedicar mayor esfuerzo y creatividad al campo de la investigación, que hasta ahora ha dado respuestas importantes pero aún insuficientes.

Al reflexionar sobre la violencia, que es la sustitución de toda argumentación por la fuerza, es necesario ubicarla en el contexto de la vida y la salud. No se pretende solo racionalizarla, y menos aún sustituir la acción por la palabra o por las reflexiones, sino tratar de comprenderla a fondo con el objeto de buscarle alternativas.

En el presente artículo se analiza, con esta finalidad, el tema de la violencia en Colombia, principalmente desde el punto de vista de su efecto en la salud de los colombianos y de sus implicaciones para el sector sanitario. El autor expone sus puntos de vista con plena conciencia de su subjetividad y limitaciones. 